\title{
A Novel Depurination Methodology to Assess DNA Alkylation of Chloro-Bis-Seco-Cyclopropylbenzoindoles Allowed for Comparison of Minor-Groove Reactivity ${ }^{\text {『 }}$
}

\author{
Shuai Wang, Buyun Chen, Peter Dragovich, Thomas Pillow, Leanna Staben, Jun Guo, Dian Su, \\ Chenghong Zhang, Sudheer Bobba, Yong Ma, Jianshuang Wang, Dewakar Sangaraju, \\ BinQing Wei, Gail Lewis Phillips, Cyrus Khojasteh, and Donglu Zhang
}

Drug Metabolism and Pharmacokinetics (S.W., B.C., D.Su., C.Z., S.B., Y.M., J.W., D.Sa., C.K., D.Z.), Discovery Chemistry (P.D., T.P., L.S., B.W.), and Discovery Biology (J.G., G.L.P.), Genentech, Inc., South San Francisco, California

Received October 29, 2018; accepted January 25, 2019

\begin{abstract}
Duocarmycins [including cyclopropyl pyrroloindole (CPI) or cyclopropyl benzoindole (CBI)] are a class of DNA minor-groove alkylators and seco-CPI/CBIs are synthetic pro-forms that can spirocyclize to $\mathrm{CPI} / \mathrm{CBI}$. Bis-CPI/CBIs are potential drug candidates because of their enhanced cytotoxicity from DNA crosslinking, but it is difficult to analyze them for structure-activity correlation because of their DNA reactivity. To study their DNA alkylation, neutral thermal hydrolysis has been frequently applied to process depurination. However, unwanted side reactions under this condition have been reported, which could lead to poor correlation of DNA alkylation data with efficacy results, especially for bis-CPI/CBIs. In this study, an acidic depurination method was developed and applied for analysis of DNA alkylation and shown to be an easier and milder method than the traditional neutral thermal hydrolysis. DNA alkylation and stability of three bis-seco-CBls were characterized in comparison with two mono-seco-CPIs. The results suggested that: 1 ) The acidic
\end{abstract}

depurination method was capable of capturing a more representative population, sometimes a different population, of DNA adducts as they existed on DNA compared with the heat depurination method. 2) Di-adenine adducts were captured as expected for the $\mathrm{CBI}$ dimers, although the major type of adduct was still mono-adenine adducts. 3) The rate of DNA alkylation, DNA adduct profile, and relative amounts of di-adduct versus mono-adduct were significantly affected by the size, and possibly lipophilicity, of the nonalkylating part of the molecules. 4) Spirocyclization and amide hydrolysis represented two major pathways of degradation. Overall, by applying acidic depurination analyses, this study has illustrated DNA adduct characteristics of novel bis-seco-CBls with dominating monoalkylation and provides an alternative method for evaluating DNA minor-groove alkylators. These findings provide an effective analytical tool to evaluate DNA alkylators and to study the DNA alkylation that is a disposition mechanism of these compounds.

\section{Introduction}

Duocarmycins are a series of compounds first discovered in Streptomyces (Yasuzawa et al., 1995). These compounds display picomolar cell-killing activities that are related to their potent sequence-selective DNA alkylation (Tichenor et al., 2007; MacMillan and Boger, 2009). The cyclopropyl pyrroloindole (CPI) group in these molecules acts as an electrophile upon binding in the DNA minor groove, favoring an attack on the adenine N3 position (Boger and Johnson, 1995) (Scheme 1). The naturally occurring $S$ conformation is also important, with much higher activity (500-fold) over the $R$ isoforms (Boger and Garbaccio, 1999b; Tietze and von Hof, 2011). Modification of the CPI group by replacing the pyrrole ring with a benzene ring leads to increased stability, potentially owing to less strain from the ring expansion. Additionally, the resultant cyclopropyl benzoindole (CBI) compounds also display more potent DNA alkylation and cytotoxicity (Boger et al., 1991).

Molecules containing two CPI groups have been developed to achieve higher potency from intra- and interstrand DNA crosslinking

https://doi.org/10.1124/dmd.118.085209.

S This article has supplemental material available at dmd.aspetjournals.org.
(Mitchell et al., 1989; Boger et al., 2000). Most notably, bizelesin, a CPI-dimer, was evaluated in a phase I clinical trial for advanced solid tumors (Schwartz et al., 2003). Mitchell et al. (1989) synthesized several CPI dimers and found an optimal chain length of three carbons with a 2-pM in vitro $\mathrm{IC}_{50}$. Jia and Lown (2000) also reported seco-CBI dimers linked with three carbons showing the highest in vitro potency. Consistent with these findings, bis-seco-CPIs connected by a 3,3'-(1,4phenylene)diacryloyl group had previously shown superior cytotoxicity, with an in vitro $\mathrm{IC}_{50}$ of $2.7 \mathrm{pg} / \mathrm{ml}$ compared with $60 \mathrm{pg} / \mathrm{ml}$ for bizelesin, and inhibited xenograft tumor growth at $0.254 \mu \mathrm{g} / \mathrm{kg}$ compared with $3.72 \mu \mathrm{g} / \mathrm{kg}$ by bizelesin in vivo with 4 -fold higher therapeutic index (Fukuda et al., 1998). However, these therapeutics inevitably suffer from off-target toxicity and severe side reactions (McGovren et al., 1984; Baraldi et al., 2004).

Antibody drug conjugates (ADC) are a class of compounds that use the specificity of antibody-antigen interaction to achieve targeted delivery of small molecule payloads. Their high selectivity has allowed the use of potent cytotoxins as the payload to kill cancer cells. Compounds such as tubulin inhibitors, topoisomerase inhibitors, and DNA minor-groove alkylators have been used as ADC payloads (Anderl et al., 2013; Polakis, 2016). With this as an objective, duocarmycins were made and

ABBREVIATIONS: ADC, antibody drug conjugate; $\mathrm{CBI}$, cyclopropyl benzoindole; CPI, cyclopropyl pyrroloindole; LC-, liquid chromatography; MS/MS, tandem mass spectrometry; XIC, extracted ion chromatogram. 

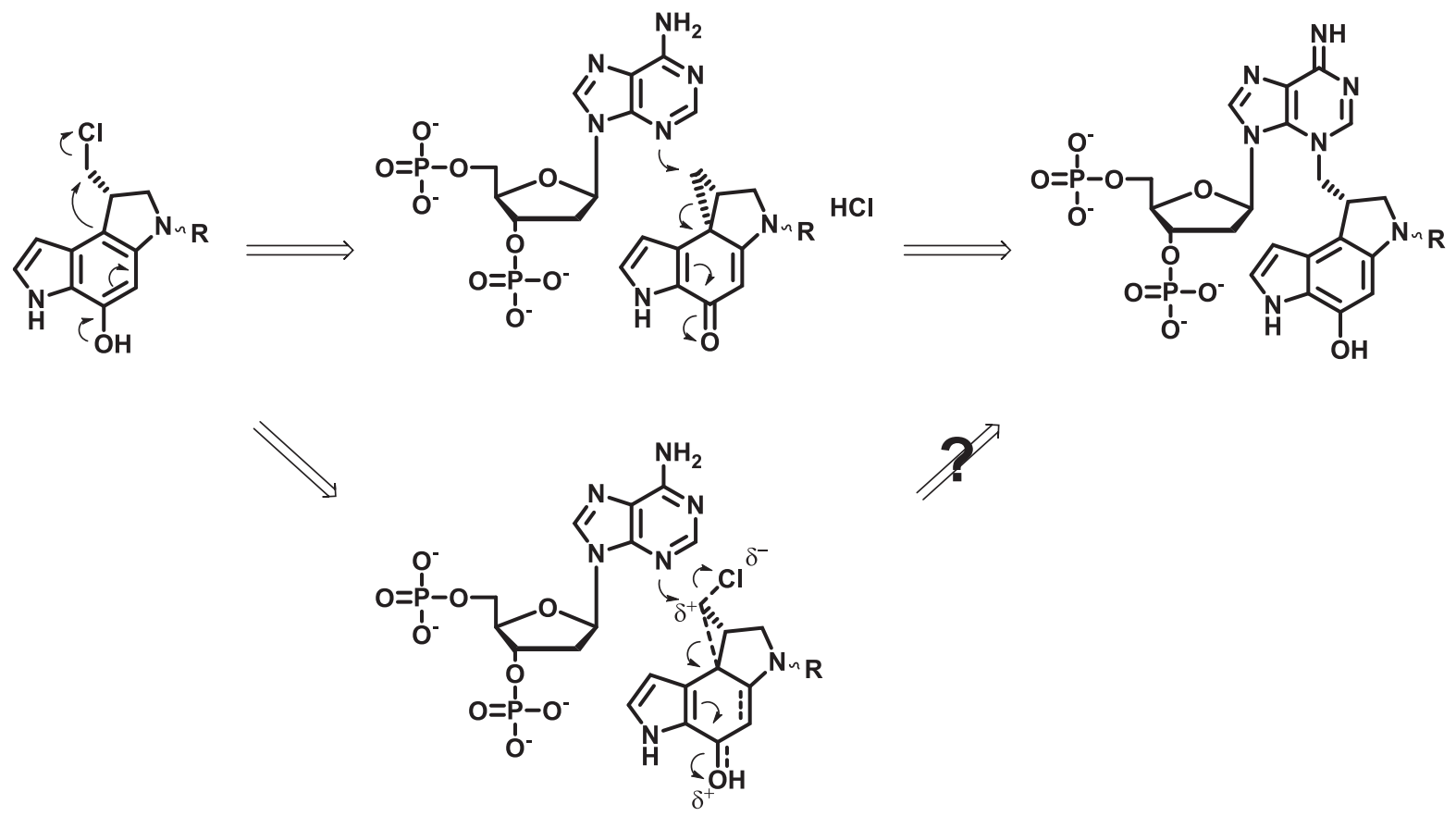

Scheme 1. Seco-CPI spirocyclization and DNA alkylation.

experiments were carried out to understand their DNA alkylation mechanisms. In this study, several bis-chloro-seco-CBIs, including compounds $\mathbf{4}$ and $\mathbf{5}$, were synthesized with the CBI dimers connected by a 3,3'-(1,4-phenylene)diacryloyl group. Additionally, these compounds carry different types of side chains, with variable lengths serving as handles for the antibody linkage. The DNA alkylation by duocarmycins is not only a mechanism of pharmacological activity but also serves as a process for cells to eliminate these compounds (Kiakos et al., 2007; Ghosh et al., 2010). Since DNA adducts have not been systemically characterized before for bis-CBI compounds, to the best of our knowledge, the DNA alkylation of bis-seco-CBIs $\mathbf{4}$ and $\mathbf{5}$ were characterized in comparison with bis-seco-CBI $\mathbf{3}$ and two mono-seco-CPIs $\mathbf{1}$ and $\mathbf{2}$ (Fig. 1). CPI monomers $\mathbf{1}$ and $\mathbf{2}$ are the chloro-seco-forms of a synthetic duocarmycin analog with a methyl group on the pyrrole ring and the natural compound duocarmycin SA (Mitchell et al., 1993; Robertson et al., 2010). Bis-seco-CBI 3 with a $0.1-$ pM in vitro potency previously showed DNA crosslinking activity, but bis-DNA adducts were not detected from in vitro DNA incubations by liquid chromatography-mass spectrometry (LC-MS) (Tercel et al., 2013). For this study, we developed and applied a novel method to induce the depurination by an acid for this class of compounds and revealed more information regarding the DNA adduct profile and reaction mechanisms, as the acidic depurination method was capable of capturing a more representative population, sometimes a different population, of DNA adducts as they existed on DNA compared with the heat depurination method that generated artificial products. The types of adducts were characterized and the extent and kinetics of adduct formation were measured. To examine the extent of bis-alkylation and the mechanism of alkylation by bis-seco-CBIs, di-adduct versus mono-adduct ratios were also determined. Additionally, stability of the payloads was further studied as the stability together with potency of the payloads drive the in vivo efficacy (Zhang et al., 2018).

\section{Materials and Methods}

Materials. Reagents and buffers were purchased from Sigma-Aldrich if not otherwise specified. The DNA solution was prepared by dissolving genomic calf<smiles>COc1cc2cc(C(=O)N3C[C@@H](CCl)c4c3cc(O)c3[nH]cc(C)c43)[nH]c2c(OC)c1OC</smiles>

1<smiles>COC(=O)c1cc2c3c(cc(O)c2[nH]1)N(C(=O)c1cc2cc(OC)c(OC)c(OC)c2[nH]1)C[C@H]3CCl</smiles>

2<smiles>O=C(CCCC(=O)N1CC(Cl)c2c1cc(O)c1ccccc21)N1CC(Cl)c2c1cc(O)c1ccccc21</smiles>

3<smiles>Nc1cc(/C=C/C(=O)N2CC(Cl)c3c2cc(O)c2ccccc32)ccc1/C=C/C(=O)N1CC(CCl)c2c1cc(O)c1ccccc21</smiles>

4<smiles>NCCC(=O)Nc1cc(/C=C/C(=O)N2CC(CCl)c3c2cc(O)c2ccccc32)ccc1/C=C/C(=O)N1CC(CCl)c2c1cc(O)c1ccccc21</smiles>

Fig. 1. Structures of CBI/CPI compounds used in this study. Six seco-CBI/CPI monomer or dimer compounds were used in this study: Compounds 1 and 2 are seco-CPI monomers and compounds $\mathbf{3}, \mathbf{4}$, and $\mathbf{5}$ are seco-CBI dimers. 
thymus DNA in water with gentle rocking overnight to a final concentration of $1 \mathrm{mg} / \mathrm{ml}$. Self-complimentary oligomer DNA $5^{\prime}$-CGCCTTATAAGGCG- ${ }^{\prime}$ ' was designed to have two adenines $0-2 \mathrm{bp}$ apart on the same chain or $0-4$ bp apart on different chains. The oligonucleotides were synthesized at Genentech. The self-complimentary oligomer was dissolved in $10 \mathrm{mM}$ Tris- $\mathrm{HCl}$ buffer to a final concentration of $1 \mathrm{mM}$; the solution was heated to $90^{\circ} \mathrm{C}$ for 5 minutes for annealing and then cooled down to room temperature before use. Compounds 1-5 (Fig. 1) were synthesized at Genentech with a purity $>95 \%$, and detailed synthesis will be published elsewhere.

Sample Processing. Compounds were initially dissolved in dimethyl sulfoxide as stock solutions at $10 \mathrm{mM}$. Compounds $(10 \mu \mathrm{M})$ were incubated in $10 \mathrm{mM}$ Tris-HCl buffer ( $\mathrm{pH} 7.4)$ alone for stability study or in the presence of $0.5 \mathrm{mg} / \mathrm{ml}$ calf thymus DNA or $100 \mu \mathrm{M}$ oligodeoxyribonucleotide for DNA alkylation study. In the kinetics study, equal volumes of the same sample were aliquoted at different time points after vortex mixing and were immediately stored in $-80^{\circ} \mathrm{C}$ freezer until analysis. Prior to LC-MS analysis, samples were diluted and processed for depurination as follows: four times dilution with water as the control group, four times dilution with $0.1 \%$ formic acid as the acid hydrolysis group, or four times dilution with water and heated at $90^{\circ} \mathrm{C}$ for 10 minutes as the neutral thermal hydrolysis group. DNA precipitation was also conducted for comparison in which incubation mixture was mixed with three volumes of acetonitrile and centrifuged at $15,000 \mathrm{~g}$ for 15 minutes. The supernatant was removed, and another three volumes of acetonitrile was added to wash away the residual free compounds and centrifuged to remove acetonitrile. The DNA pellet was then resuspended in $10 \mathrm{mM}$ Tris- $\mathrm{HCl}$ buffer ( $\mathrm{pH}$ 7.4) and processed for depurination as described above.

Mass Spectrometry Analysis By Ultra-High Performance Liquid Chromatographic Method Coupled with Ultraviolet Detector. The incubation samples were analyzed by ultra-high performance liquid chromatographic method coupled with ultraviolet detector (UHPLC-UV) with tandem mass spectrometry (MS/MS) using Dionex Ultimate 3000 LC Systems coupled with Thermo Q Exactive Plus mass spectrometer operated in positive electrospray ionization mode. For UHPLC-UV-MS analysis, the capillary temperature was set at $265^{\circ} \mathrm{C}$, the source potential was $3500 \mathrm{~V}$ and the source heater was set at $425^{\circ} \mathrm{C}$. The mass spectrometer was operated in the data-dependent scanning mode to MS/MS with dynamic exclusion enabled. The normalized collision energy for the data-dependent scan was 30 . Other potentials were adjusted to get the optimal ionization and fragmentation of the parent compounds. UV absorption spectra were obtained with the in-line diode array detector. A Thermal Hypersil GOLD C18 column $(100 \mathrm{~mm} \times 2.1 \mathrm{~mm}, 1.9 \mu \mathrm{m})$ or a Luna Omega C18 $100 \AA$ A column was used $(100 \mathrm{~mm} \times 2.1 \mathrm{~mm}, 1.6 \mu \mathrm{m})$, and the compounds were eluted by a gradient of mobile phase A $(0.1 \%$ formic acid in water or $20 \mathrm{mM}$ ammonium acetate in water, $\mathrm{pH} 8.0$ ) and mobile phase $\mathrm{B}$ (acetonitrile) (5\% B 0-2 minutes, 5\%-20\% B 2-3 minutes, 20\%-75\% B 3-13 minutes, 75\%-95\% B 13-15 minutes, 95\% B $15-17$ minutes, 95\%-5\% B 17-17.2 minutes, and 5\% B 17.2-20 minutes) at a flow rate of $0.4 \mathrm{ml} / \mathrm{min}$ at $35^{\circ} \mathrm{C}$. Relative quantities of compound-related components were estimated by mass response or UV peaks.

Cell Killing Assay. Cells were seeded in a 384-well plate (for BJAB, seeded at 10,000 cells/well) where $54 \mu 1$ of Dulbecco's modified Eagle's medium/F-12 cell culture medium was supplemented with $10 \%$ fetal bovine serum in each well, and after 24 hours, they were treated with compounds 1-5 (1:3 serial dilution with last one as medium control, quadruplicate for each concentration). Cells were incubated in a humidified incubator set at $37^{\circ} \mathrm{C}$ and an atmosphere of $5 \% \mathrm{CO}_{2}$. After 4 days of drug incubation, the cell viability was determined using Promega CellTiter-Glo luminescent reagent, which measures ATP level (an indirect measure of cell number). The luminescent intensity was measured on PerkinElmer Envision reader. The relative cell viability was calculated by normalizing to nondrug treatment control and was graphed using KaleidaGraph software package. The $\mathrm{IC}_{50}$ value was determined as the concentration to obtain $50 \%$ of the maximum cell killing and is shown in Table 1 .

\section{Results}

Acidic Depurination. During the initial work of DNA incubation with bis-seco-CBIs, DNA adducts were unexpectedly detected in the incubation mixture by LC-MS/MS, using an acidic mobile phase without a prior depurination step. To test if these adducts were formed as a result of an unknown spontaneous depurination process, the samples
TABLE 1

In vitro cell-killing $\mathrm{IC}_{50}$ values (picomolar) of compounds $\mathbf{1 - 5}$ in six different cancer cell lines after 4 days of incubation

\begin{tabular}{lcccccc}
\hline Compound & KPL-4 & SK-BR-3 & T-47D & HCC1937 & NCI-H1781 & SW 900 \\
\hline 1 & 3.6 & 9.8 & 20 & 25 & 1.7 & 1.6 \\
2 & 36 & 53 & 94 & 72 & 17 & 18 \\
3 & 1.5 & 1.6 & 2.1 & 29 & 0.47 & 8.8 \\
4 & 3.7 & 2.4 & 2.7 & 16 & 1.7 & 1.1 \\
5 & 92 & 150 & 75 & 430 & 45 & 27 \\
\hline
\end{tabular}

HCC1937, Her2 negative; KPL-4, Her2 positive; NCI-H1781, Her2 mutant; SK-BR-3, Her2 overexpression; SW 900, lung cancer cell line; T-47D, Her2 negative.

were mixed with ethyl acetate (EA). The organic portion and aqueous portion were subsequently separated and analyzed via LC-MS/MS. However, the results showed that DNA adducts were barely detectable in the organic portion, whereas the aqueous portion still showed abundant DNA adduct peaks (Supplemental Fig. 1). This observation ruled out a spontaneous depurination and indicated that the depurination occurred after samples were injected into the liquid chromatograph. It was later determined that the acidic condition of the mobile phase led to a rapid on-column depurination. When the aqueous mobile phase A was switched from $0.1 \%$ formic acid to ammonium acetate buffer at $\mathrm{pH} 8$, the DNA adducts were no longer captured (Supplemental Fig. 2). Consequently, the basic LC condition was used throughout the rest of the study. The novel acidic depurination method was thus applied to this study from this knowledge by adding four volumes of $0.1 \%$ formic acid post-adduct-formation step in comparison with the traditional neutral thermal hydrolysis (heat) depurination treatment.

Reaction Profile and DNA Adduct Identification. The chloro-seco$\mathrm{CPI} / \mathrm{CBI}$ compounds were incubated with genomic DNA at $37^{\circ} \mathrm{C}$ for 48 hours The samples were then split into three portions and processed with: 1) no treatment, 2) acidic depurination, or 3) heat depurination. The characterizations of depurination and degradation products are listed in Supplemental Table 1. For seco-CPI monomer 1, the UV chromatograms of acidic and heat depurination samples indicated the formation of a major UV peak at 7.86 minutes (1b) compared with the no treatment control (Supplemental Fig. 3A). The extracted ion chromatogram (XIC) of the proposed adenine adduct $\mathbf{1 b}$ confirmed the corresponding peak at 7.90 minutes with a 0.04 -minute in-line delay from the UV detector. Its fragmentation pattern also matched that of the parent compound with an additional ion of 136.0612 corresponding to the adenine fragment (Supplemental Table 1). Smaller peaks at the same retention time from XIC of spirocyclized 1a and amide hydrolysis product 1c probably resulted from in-source fragmentation of $\mathbf{1 b}$. Neither the parent compound $\mathbf{1}$ nor the cyclopropyl form $\mathbf{1 a}$ was detected after the incubation, indicating a complete reaction. Scrutinization of the MS data also found trace levels of amide hydrolysis product 1c, which did not show up as intense peaks in the UV chromatograms.

CPI monomer 2 had comparable results with 1 (Supplemental Fig. 3B). One major peak at 7.90 minutes (2b) was observed with both the acidic and heat depurination samples and identified to be the adenine adduct of $\mathbf{2}$ by both exact mass and fragmentation patterns. Small amounts of compound 2 were still detectable in the control and acidic depurination samples but not in the heat depurination sample (small peak at 11.00 minutes). The cyclopropyl form (2a) was detected in the heat depurination sample, probably from conversion of the residual parent compound $\mathbf{2}$ and reverse alkylation from adenine adduct $\mathbf{2} \mathbf{b}$ under heating condition. The amide hydrolysis products $\mathbf{2 c}$ and $\mathbf{2 d}$ were also detected in these samples.

CBI dimers were expected to have a much more complex profile owing to potential mixed fates of the two CBI units. Compound 3 is a bis-seco-CBI containing a three-carbon chain. Unlike CPI monomers $\mathbf{1}$ and $\mathbf{2}$, compound $\mathbf{3}$ was still the major form present after the 
incubation, indicating a less extensive alkylation (Supplemental Fig. 3C). The spirocyclization products $\mathbf{3} \mathbf{a}$ and $\mathbf{3 b}$ occurred under the no treatment condition. Two new major UV peaks at 8.20 and 8.58 minutes and a small peak at 10.22 minutes were observed in the acidic depurination sample, corresponding to the di-adenine adduct $\mathbf{3 f}$, hydroxyl mono-adenine adduct 3e, and chloro-mono-adenine adduct 3c, respectively. Cyclopropyl mono-adenine adduct $\mathbf{3 d}$ was detected as a minor adduct. Amide hydrolysis products $\mathbf{3 g}$ and $\mathbf{3 h}$ were also observed, and $\mathbf{3 g}$ corresponded to the UV peak at 6.12 minutes. However, the heat depurination sample exhibited a quite different profile. The UV chromatogram of heat depurination sample showed generally less abundant depurinated DNA adducts. Specifically, the abundant di-adenine adduct $\mathbf{3 f}$ and the chloromono-adenine adduct 3c captured in the acidic depurination sample were not captured after heat depurination. On the other hand, abundant cyclopropyl $\mathbf{3 b}$ and cyclopropyl mono-adenine adduct $\mathbf{3 d}$ with equal or higher signal were observed.

For compound 4, UV chromatograms indicated no apparent differences qualitatively between the samples processed with acidic or heat depurination, with major peaks corresponding to the parent compound 4 (13.68 minutes), mono-spirocyclization products $\mathbf{4 a}$ and $\mathbf{4 b}$ (a doublet at 12.50 and 12.61 minutes), and di-cyclopropyl $\mathbf{4 c}$ (11.19 minutes) (Supplemental Fig. 3D). Accordingly, small peaks of chloro-monoadenine adduct $\mathbf{4 d} / \mathbf{4 e}$ (single peak) with acidic depurination and cyclopropyl mono-adenine adducts $\mathbf{4 f} / \mathbf{4 g}$ by heat depurination were detected. Di-adenine adduct $\mathbf{4 h}$ was detected with much lower signal than the mono-adenine adducts. Amide hydrolysis product $\mathbf{3 g}$ was also captured likewise to compound $\mathbf{3}$.

Compound 5 had a more extended side chain than $\mathbf{4}$. From the UV chromatograms, parent compound $\mathbf{5}$ (11.88 minutes), mono-spirocyclization products $5 \mathbf{a}$ and $\mathbf{5 b}$ (10.47 and 10.62 minutes), and di-cyclopropyl 5c ( 9.13 minutes) were present after the incubation (Supplemental Fig. 3E). The acid-treated sample had a large peak at 9.70 minutes with several other minor peaks, whereas the heat-treated sample showed relatively smaller peaks and was absent of the peak at 9.70 minutes. Fragmentation and XIC chromatograms indicated the major adduct in the acidic depurination sample being chloro-mono-adenine adduct $\mathbf{5 d} / \mathbf{5 e}$ corresponding to the peak at 9.70 minutes. Both depurination methods detected di-adenine adduct $\mathbf{5 j}$ in smaller quantities, but cyclopropyl mono-adenine adducts $\mathbf{5 f}$ and $\mathbf{5 g}$ were only detected with heat depurination. Likewise, amide hydrolysis product $\mathbf{3 g}$ was also captured.

Chloro-mono-adenine adducts $\mathbf{3 c}, \mathbf{4 d} / \mathbf{e}, \mathbf{5 d} / \mathbf{e}$, found as major products under the acidic condition, were not detected under heating condition. The cyclopropyl adducts $\mathbf{3 d}, \mathbf{4 f} / \mathbf{g}, \mathbf{5 f} / \mathbf{g}$ detected under the heating condition instead were probably artificially converted from those respective chloro-mono-adenine adducts $3 \mathbf{c}, 4 \mathbf{d} / \mathbf{e}, 5 \mathrm{~d} / \mathbf{e}$ that were originally existed on DNA under the heating condition.

DNA Adduct Formation Kinetics and Di- to Mono-Adduct Ratios. Compound $\mathbf{5}$ was selected for studying the kinetics of DNA adduct formation. From incubation with genomic DNA, time-dependent increases in the four DNA adducts, chloro-mono-adenine adducts $\mathbf{5 d} / \mathbf{5 e}$, hydroxyl mono-adenine adducts $\mathbf{5 h} / \mathbf{5 i}$, cyclopropyl monoadenine adducts $\mathbf{5 f} / \mathbf{5 g}$, and di-adenine adduct $\mathbf{5} \mathbf{j}$, were observed, with chloro-mono-adenine adducts $\mathbf{5 d} / \mathbf{5 e}$ being the major adducts after acidic hydrolysis (Fig. 2; Table 2). The DNA adducts were formed in a time-dependent manner in the first 24 hours of incubation. However, when the samples were processed with neutral thermal hydrolysis, di-adenine adduct $\mathbf{5 j}$ represented the major adduct, with cyclopropyl mono-adenine adducts $\mathbf{5 f} / \mathbf{5 g}$ and hydroxyl mono-adenine adducts $\mathbf{5 h} / \mathbf{5 i}$ being the minor adducts. By incubation of compound $\mathbf{5}$ with a designed oligomer of 14 bp (5'-CGCCTTATAAGGCG-3'), chloromono-adenine adduct $\mathbf{5 d} / \mathbf{5 e}$ was again captured as the most abundant
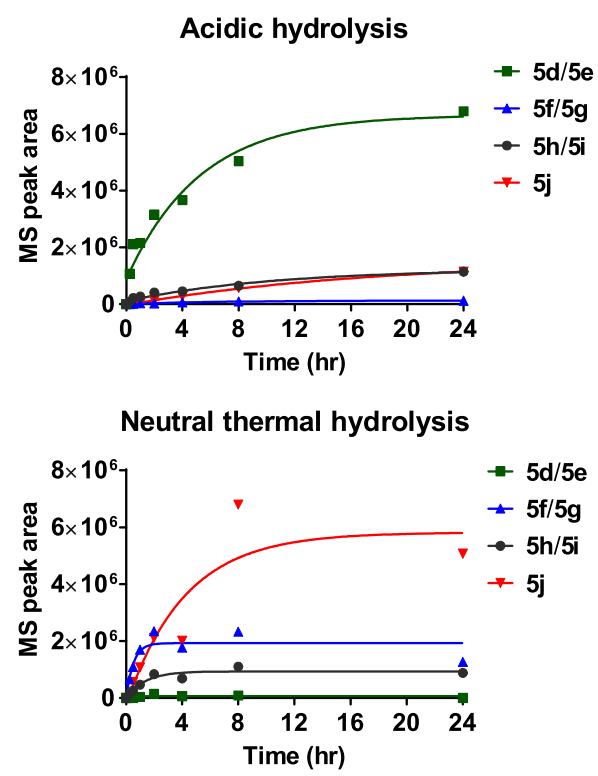

Fig. 2. Kinetics of DNA adduct formation and mono-adduct/di-adduct ratios with dimer-CBI. Time-dependent release of DNA adducts from compound $\mathbf{5}$ was plotted under two different depurination conditions. Ratios of major mono-adduct/di-adduct from compounds $\mathbf{3}, \mathbf{4}$, and $\mathbf{5}$ were graphed with UV peak area calculations.

adduct with time-dependent formations at $37^{\circ} \mathrm{C}, 25^{\circ} \mathrm{C}$, or $4^{\circ} \mathrm{C}$ (Table 3). For the seco-CPI/CBI class of compounds, DNA alkylation could be one of the clearance pathways.

Since the bis-seco-CBI were designed to have more potent cell-killing activity from intra- or interstrand crosslinking, the relative amounts of di-adduct versus mono-adduct were calculated for the CBI dimers (Fig. 3 ). For compound $\mathbf{5}$, chloro-mono-adenine adduct $\mathbf{5 d} / \mathbf{5 e}$ and hydroxyl mono-adenine adduct $\mathbf{5} \mathbf{h} / \mathbf{5 i}$ were the major mono-adducts determined and $\mathbf{5} \mathbf{j}$ was the only di-adduct, thus the $\mathbf{5} \mathbf{j}$ to $\mathbf{5} \mathbf{d} / \mathbf{5} \mathbf{e}+\mathbf{5 h} / \mathbf{5 i}$ ratio was determined on the basis of UV signals. As with compound $\mathbf{5}$, the most abundant adducts from compounds $\mathbf{3}$ or $\mathbf{4}$ were used for the calculation. After the incubation, the di- to mono-adduct ratios for compounds $\mathbf{3}, \mathbf{4}$, and 5 were $0.71,0.67$, and 0.08 , respectively. This result demonstrated the significantly different DNA adduct profiles of these CBI dimers, although all of them had dominating mono-alkylation. The higher di- to mono-adduct ratios for compounds $\mathbf{3}$ and $\mathbf{4}$ than $\mathbf{5}$ is consistent with their cell-killing potential with $\mathbf{5}$ being less potent (Table 1).

Payload Stability and Degradation. Degradation of the CPI monomers in buffer is mainly characterized by the spirocyclization resulting in the cyclopropyl form being the major form after 24 hours of incubation for both CPI-monomers (Fig. 4, A and B). The cyclopropyl forms correspond to the largest peaks at 9.61 minutes for compound $\mathbf{1}$ and 9.68 minutes for compound 2 . Since the cyclopropyl forms of the compounds still contain the same designed activity, this particular degradant should not affect the effectiveness of the payload. Amide hydrolysis represents another major degradation pathway for these chloro-seco-CPI/CBI compounds, with detection of $\mathbf{2 c}$ and $\mathbf{2 d}$ as the main products. Additionally, solvolysis product $2 \mathbf{e}$ was observed in relatively low quantities, likewise to a previous report (Boger and Garbaccio, 1999a).

Comparatively, incubation of compound $\mathbf{3}$ in buffer showed two small peaks in the UV chromatogram corresponding to di-cyclopropyl $\mathbf{3 b}$ and amide hydrolysis product $\mathbf{3 g}$ (Fig. 4C). Compound $\mathbf{4}$ was more stable than compound $\mathbf{3}$, with compound $\mathbf{4}$, mono-cyclopropyl $\mathbf{4 a}$ and $\mathbf{4 b}$, and di-cyclopropyl $\mathbf{4 c}$ present in the UV chromatogram and $\mathbf{3 g}$ only detected by mass spectrometry (Fig. 4D). Incubation of compound 5 in buffer also resulted in detection of compound $\mathbf{5}$ and mono- and 
TABLE 2

Normalized time-dependent DNA adduct profile of compound $\mathbf{5}$ and genomic DNA incubations (data normalized to compound $\mathbf{5}$ MS peak area at 0.25 h in the acidic depurination group)

\begin{tabular}{|c|c|c|c|c|c|c|c|c|c|c|}
\hline \multirow{2}{*}{ Depurination } & & \multirow{2}{*}{ Compounds and Reactions } & \multirow{2}{*}{ R.T. (min) } & \multicolumn{7}{|c|}{ Relative Amount of Products } \\
\hline & & & & $0.25 \mathrm{~h}$ & $0.5 \mathrm{~h}$ & $1 \mathrm{~h}$ & $2 \mathrm{~h}$ & $4 \mathrm{~h}$ & $8 \mathrm{~h}$ & $24 \mathrm{~h}$ \\
\hline \multirow[t]{7}{*}{ Formic acid } & 5 & & 11.9 & 1.0 & 0.57 & 0.44 & 0.41 & 0.36 & 0.41 & 0.25 \\
\hline & $\mathbf{5 a} / \mathbf{5} \mathbf{b}$ & Mono-spirocyclization & $10.5,10.6$ & 0.45 & 0.20 & 0.13 & 0.12 & 0.12 & 0.29 & 0.23 \\
\hline & $5 c$ & Di-spirocyclization & 9.1 & 0.20 & 0.09 & 0.06 & 0.05 & 0.05 & 0.17 & 0.15 \\
\hline & $5 d / 5 e$ & Mono-adenine alkylation & 9.7 & 0.14 & 0.27 & 0.28 & 0.41 & 0.47 & 0.65 & 0.88 \\
\hline & $\mathbf{5 f} / \mathbf{5 g}$ & Adenine alkylation and spirocyclization & 8.5 & 0 & 0 & 0 & 0 & 0.01 & 0.01 & 0.02 \\
\hline & $\mathbf{5 h} / \mathbf{5 i}$ & Adenine alkylation and hydroxylation & 8.3 & 0.01 & 0.03 & 0.03 & 0.05 & 0.06 & 0.08 & 0.15 \\
\hline & $\mathbf{5 j}$ & Di-adenine alkylation & 8 & 0 & 0 & 0 & 0.02 & 0.04 & 0.07 & 0.15 \\
\hline \multirow[t]{7}{*}{ Heating } & 5 & & 11.9 & 0.13 & 0.27 & 0.23 & 0.31 & 0.33 & 0.16 & 0.04 \\
\hline & $\mathbf{5 a} / \mathbf{5} \mathbf{b}$ & Mono-spirocyclization & $10.5,10.6$ & 0.09 & 0.51 & 0.27 & 0.57 & 0.81 & 0.07 & 0.01 \\
\hline & $5 c$ & Di-spirocyclization & 9.1 & 0.34 & 1.05 & 0.58 & 1.49 & 1.75 & 0.30 & 0.04 \\
\hline & $5 d / 5 e$ & Mono-adenine alkylation & 9.7 & 0 & 0 & 0 & 0.02 & 0.01 & 0.01 & 0 \\
\hline & $\mathbf{5 f} / \mathbf{5 g}$ & Adenine alkylation and spirocyclization & 8.5 & 0.09 & 0.14 & 0.22 & 0.30 & 0.23 & 0.30 & 0.16 \\
\hline & $5 \mathrm{~h} / \mathbf{5 i}$ & Adenine alkylation and hydroxylation & 8.3 & 0.02 & 0.03 & 0.06 & 0.11 & 0.09 & 0.14 & 0.11 \\
\hline & $\mathbf{5 j}$ & Di-adenine alkylation & 8 & 0 & 0.07 & 0.14 & 0.27 & 0.26 & 0.88 & 0.66 \\
\hline
\end{tabular}

R.T., retention time.

di- spirocyclization products $\mathbf{5 a}, \mathbf{5 b}$, and $\mathbf{5 c}$, with di-cyclopropyl $\mathbf{5 c}$ being the major peak (Fig. 4E). High levels of amide hydrolysis products $\mathbf{3 g}$ and $\mathbf{5 k} / \mathbf{5 l}$ were also detected. Compound $\mathbf{5}$ showed more rapid degradation at higher temperatures as expected, with $2.5 \%, 10 \%$, and $20 \%$ of parent remaining after incubation in buffer at $37^{\circ} \mathrm{C}, 25^{\circ} \mathrm{C}$, or $4^{\circ} \mathrm{C}$ for 48 hours (Supplemental Fig. 4; Table 4). In the presence of DNA, however, stability of the compounds was significantly increased. In comparison, around $25 \%$ of compound 5 was still present after 24 hours at $37^{\circ} \mathrm{C}$ with genomic DNA present (Supplemental Fig. 3). When DNA precipitation was performed after the incubation, a colored DNA precipitate (yellowish color from the compounds) was observed.

To bridge the differences between the two depurination methods and to further verify the chloro-mono-adenine adducts, the DNA incubation sample from compound $\mathbf{5}$ was aliquoted and heated at $25^{\circ} \mathrm{C}, 55^{\circ} \mathrm{C}, 75^{\circ} \mathrm{C}$, or $90^{\circ} \mathrm{C}$, respectively. Excitingly, a significant amount of chloro-monoadenine adduct $\mathbf{5 d} / \mathbf{5 e}$ was captured after heating at $55^{\circ} \mathrm{C}$, further verifying the existence of this chloro-adduct (Supplemental Fig. 5). As the temperature increased, the amount of $\mathbf{5 d} / \mathbf{5 e}$ decreased, which probably led to conversion to the cyclopropyl adduct forms. The increasing amount of di-adenine adduct $5 \mathbf{j}$ formation from $75^{\circ} \mathrm{C}$ to $90^{\circ} \mathrm{C}$, the temperature used in the original heat depurination method, may suggest that a higher energy was required to release di-alkylated DNA adducts. However, the heating condition may also have led to artificial reactions, including reverse dealkylation and spirocyclization. Thus, the acidic depurination was able to minimize reverse dealkylation and showed cleaner results from fewer artificial reactions in which both adducts were detected. Nonetheless, an enzymatic digestion method can be used to further compare the efficiencies of the chemical depurination and potential associated side reactions.

\section{Discussion}

Significance of Studying DNA Alkylation. Duocarmycins exert cytotoxicity through DNA minor-groove binding and alkylation, interfering with transcriptional activities and causing DNA damage (Kiakos et al., 2007; Ghosh et al., 2010). Bis-CPI/CBIs are potential drug candidates because of their enhanced cytotoxicity from DNA crosslinking, but it is difficult to analyze them for structure-activity correlation because of their DNA reactivity. In addition, DNA alkylation could be a mechanism for the clearance of the compounds from circulation, after which the bound drug could be eliminated through DNA nucleotide excision repair or degradation of DNA of lysed cells (Kiakos et al., 2007). The DNA-bound alkylators could otherwise stay and accumulate in cells (Ma et al., 2016). Thus, DNA alkylation serves both as a mechanistic process for cell killing and a clearance pathway for the duocarmycins. Understanding the DNA alkylation properties of these compounds could improve correlation of in vivo efficacy and off-target toxicity.

Depurination Method to Study Mono- and Di-DNA Alkylation. DNA adduct characterization normally requires the release of adducts from DNA, i.e., depurination. Neutral thermal hydrolysis has been extensively used previously for CPI/CBI DNA alkylation studies (Lee and Gibson, 1993; Boger and Johnson, 1996; Tercel et al., 2013). However, unwanted reverse alkylation reactions and amide hydrolysis

TABLE 3

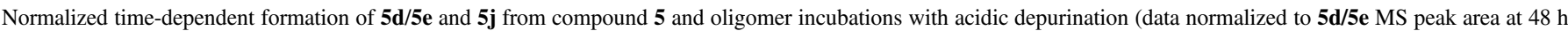
from $37^{\circ} \mathrm{C}$ incubation)

\begin{tabular}{|c|c|c|c|c|c|c|c|c|c|c|c|}
\hline \multirow{2}{*}{ Temperature $\left({ }^{\circ} \mathrm{C}\right)$} & \multirow{2}{*}{\multicolumn{2}{|c|}{ Compounds and Reactions }} & \multirow{2}{*}{ R.T. (min) } & \multicolumn{8}{|c|}{ Relative Amount of Products } \\
\hline & & & & $0.25 \mathrm{~h}$ & $0.5 \mathrm{~h}$ & $1 \mathrm{~h}$ & $2 \mathrm{~h}$ & $4 \mathrm{~h}$ & $8 \mathrm{~h}$ & $24 \mathrm{~h}$ & $48 \mathrm{~h}$ \\
\hline \multirow[t]{2}{*}{4} & $5 d / 5 e$ & Mono-adenine alkylation & 9.7 & & & & & & 0.20 & 0.52 & 0.84 \\
\hline & $\mathbf{5 j}$ & Di-adenine alkylation & 8 & & & & & & & & \\
\hline \multirow[t]{2}{*}{25} & $5 d / 5 e$ & Mono-adenine alkylation & 9.7 & & & & 0.09 & 0.51 & 1.4 & 2.0 & 2.5 \\
\hline & $\mathbf{5 j}$ & Di-adenine alkylation & 8 & & & & & & & & \\
\hline \multirow[t]{2}{*}{37} & $5 d / 5 e$ & Mono-adenine alkylation & 9.7 & & 0.06 & 0.25 & 0.64 & 0.33 & 0.99 & 0.68 & 1.0 \\
\hline & $\mathbf{5 j}$ & Di-adenine alkylation & 8 & & & & & & & & 0.26 \\
\hline
\end{tabular}

R.T., retention time. 

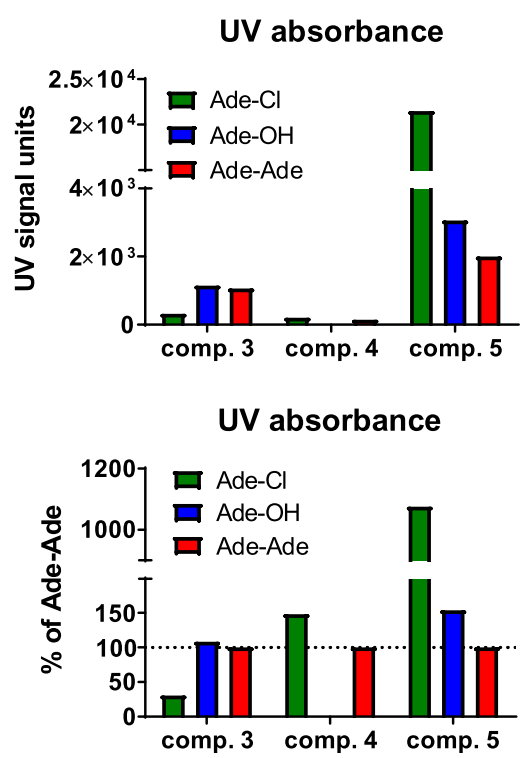

Fig. 3. UV semiquantitation of mono- and di-adducts of CBI dimers. UV peak areas were quantified from the chromatograms of acidic depurination samples of $\mathbf{3}, \mathbf{4}$, and 5 DNA incubations. Ade-Cl, mono-adenine alkylation; Ade-Ade, di-adenine alkylation; Ade-OH, adenine alkylation and hydroxylation.

have been reported especially under elevated temperatures (Warpehoski et al., 1992; Lee and Gibson, 1993; Asai et al., 1994; Elgersma et al., 2015). Acidic hydrolysis depurination has been reported (Leung et al., 2016) but not applied to CPI/CBI studies previously. In this study, acidic hydrolysis exhibited rapid and effective depurination for CPI/CBI DNA adducts (Supplemental Fig. 6), which could be attributed to a destabilized glycosidic bond from protonation of adenines (Scheme 2). Additionally, the acidic depurination process was also milder than neutral thermal hydrolysis, with detection in general of more abundant adducts that originally existed on DNA and the detection of novel chloro-mono-adenine adducts from chloro-seco-CBI dimers.

Particularly, compound $\mathbf{3}$ was previously determined to cause extensive DNA crosslinking as shown by agarose gel electrophoresis (Tercel et al., 2013). However, only cyclopropyl mono-adenine adduct (3d) was detected with LC-MS analysis. In this study, a similar result was obtained after neutral thermal hydrolysis, with 3d being the only DNA adduct detected. However, the acidic hydrolysis captured additional and abundant di-adenine adduct $\mathbf{3 f}$, which supported its DNA-crosslinking activity (Supplemental Fig. 3C). The cyclopropyl mono-adenine adduct 3d observed from neutral thermal hydrolysis was probably formed through spirocyclization of chloro-mono-adenine adduct $3 \mathbf{c}$ that existed on DNA. Reverse alkylation of di-adenine adduct 3f to form $\mathbf{3 d}$ is also possible under the heating condition. As with compounds $\mathbf{4}$ and 5, much higher levels of chloro-mono-adenine adducts were observed after acidic depurination but not with heat depurination. Under the heating condition, these chloro-mono-adenine adducts were artificially converted to the cyclopropyl forms. From this study, the DNA adduct profiles also reiterated the selective adenine alkylation nature of these seco-CPI/CBI compounds. Although detectable guanine adducts were previously reported (Mitchell et al., 1993), they were not observed in this study.

A previous study of bizelesin estimated a potential di- to monoalkylation ratio (DMR) around 0.5 using a thermal DNA-strand breakage assay (Sun and Hurley, 1993). When the extent of di-alkylation was assessed in this study, compounds $\mathbf{3}$ and $\mathbf{4}$ showed slightly higher DMR, around 0.7, whereas compound 5 had much higher level of mono-adducts over di-adducts, with a DMR less than 0.1
(Supplemental Fig. 5). The data indicated that the long side chain on the linker between CBI units in compound $\mathbf{5}$ might hamper the secondary alkylation, thus making the mono-adduct the much more dominant form. The lower extent of di-alkylation with compound $\mathbf{5}$ also correlated with a $>20$-fold lower in vitro activity compared with compounds 3 and $\mathbf{4}$ (Table 1). The similar $\mathrm{IC}_{50}$ values of compounds $\mathbf{3}$ and $\mathbf{4}$ and much higher IC $_{50}$ of compound $\mathbf{5}$ were also somewhat in line with a previous finding that smaller and more hydrophobic duocarmycins exerted more potent cytotoxicity (Wolfe et al., 2013).

Mechanism of DNA Alkylation. It is commonly accepted that spirocyclization of seco-CBI/CPI precedes its DNA alkylation, with the cyclopropane CBI/CPIs being the active forms (Jia and Lown, 2000; Kupchinsky et al., 2004; Elgersma et al., 2015). However, the results of bis-seco-CBIs from this study also supported the potential of DNA alkylation without prior spirocyclization. The observation of chloro-mono-adenine adduct $\mathbf{5 d} / \mathbf{5 e}$ as the dominant adduct form for compound $\mathbf{5}$ and much lower levels of cyclopropyl mono-adenine adduct $\mathbf{5 f} / \mathbf{5 g}$ suggested that the chloro-seco-CBI/CPIs potentially reacted with adenine without prior spirocyclization. It is hypothesized to form an electrophilic chloro-cyclopropyl intermediate, which further alkylate DNA via a similar $\mathrm{S}_{\mathrm{N}} 2$ mechanism (Scheme 1). In support of this hypothesis, previous studies from the Boger laboratory reported the DNA alkylation and cell-killing activities of synthetic mono-seco-CPIs that cannot spirocyclize owing to replacement of the hydroxyl group on the alkylation indole with a methoxy group or a hydrogen (Boger et al., 1990; Jin et al., 2007).

Another interesting observation was that although two stereoisomers were observed from spirocyclization of compounds $\mathbf{4}$ and $\mathbf{5}$, only single peaks were captured for mono-adenine adducts (Supplemental Fig. 3, D and E). One exception was the doublet peaks in the XIC chromatogram of cyclopropyl mono-adenine adduct $\mathbf{5 f} / \mathbf{5 g}$ from neutral thermal hydrolysis, which possibly resulted from spirocyclization of chloro-mono-adenine adduct $\mathbf{5 d} / \mathbf{5 e}$ and reverse alkylation of di-adenine adduct $\mathbf{5 j}$. This result supported a specific DNA binding conformation with one alkylation side much more reactive than the other and the sequential di-alkylation happening in a specific order. The DNA alkylation results from DNA and the designed oligodeoxyribonucleotide incubations were also consistent qualitatively, indicating the di-alkylation happened within 4 bp (Table 3).

Payload Stability/Degradation and DNA Alkylation Activity. Stability/degradation of these compounds under physiologic condition is also important for their in vivo efficacy (Zhang et al., 2018). MacMillan and Boger (2009) have previously shown a hyperbolic correlation between stability and DNA alkylation of CPI/CBIs, by which a fine balance between stability and reactivity enables the available CPI/CBI to reach the DNA minor groove and the alkylation of DNA through a twist-induced activation. After a 24-hour incubation in Tris- $\mathrm{HCl}$ buffer at $\mathrm{pH} 7.4$, most of the test compounds were spirocyclized to the cyclopropyl forms (Fig. 4) but still contained DNA alkylation activity. Time-dependent analysis of compound $\mathbf{5}$ showed that it had half-lives of 21,47 , and 170 minutes at $37^{\circ} \mathrm{C}, 25^{\circ} \mathrm{C}$, and $4^{\circ} \mathrm{C}$, respectively, in forming spirocyclized products (Supplemental Fig. 4; Table 4). In comparison, bizelesin was reported to have a longer half-life of 2.1 hours at $\mathrm{pH} 7$ in buffer in forming mono- and di-cyclized products (Walker et al., 1994).

Consistent with previous reports, the major degradation pathway observed was amide hydrolysis, with the release of CBI/CPI alkylating groups and loss of DNA alkylation activity (Elgersma et al., 2015). The released alkylating groups have shown $>50,000$-fold less activity and thus can also be considered as a clearance transformation pathway. The amide hydrolysis seemed to be common in these compounds. The terminal amine on the side chain of $\mathbf{5}$ potentially facilitated the hydrolysis by attacking the amide bond, resulting in compound $\mathbf{5}$ having much more 

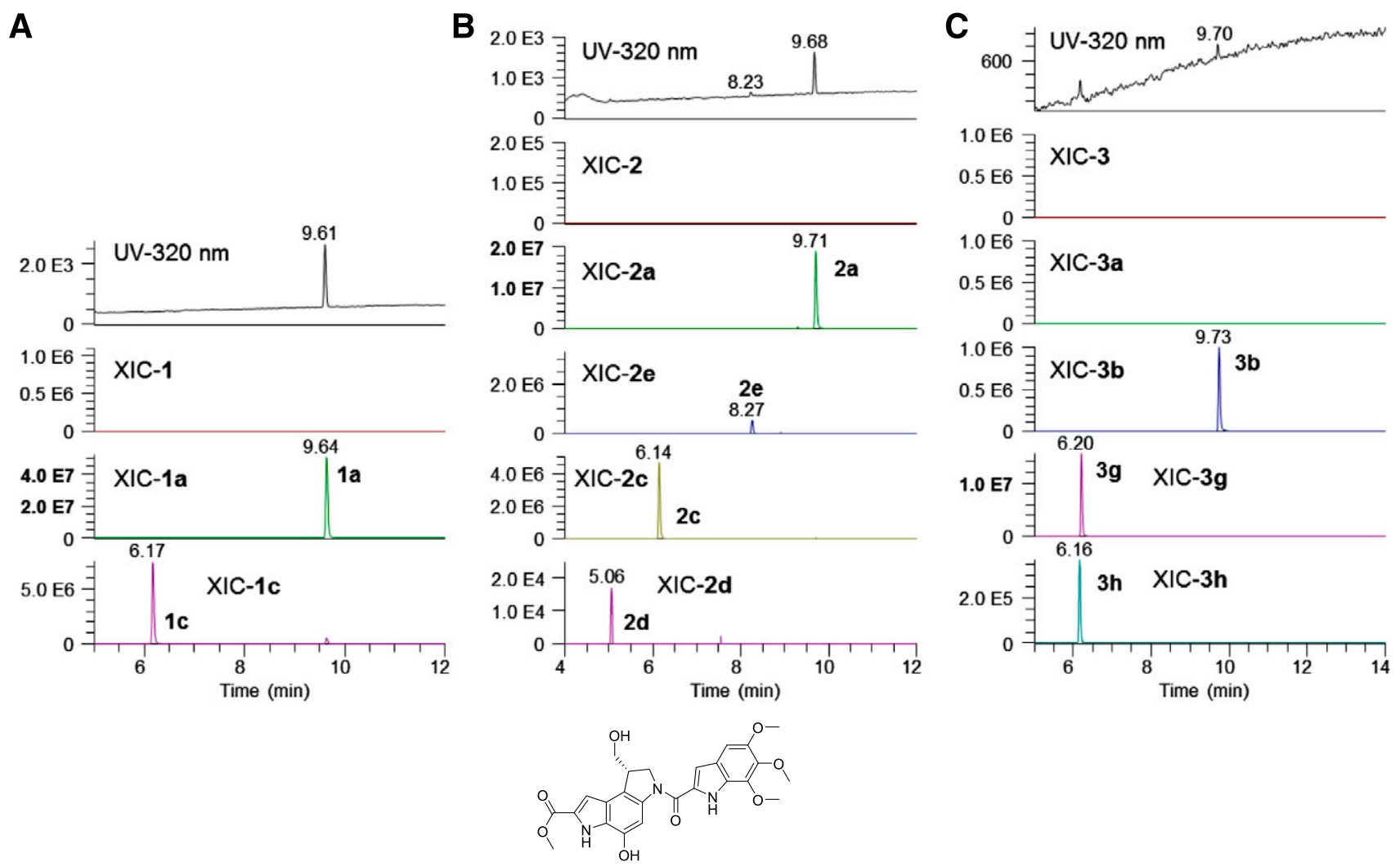

D

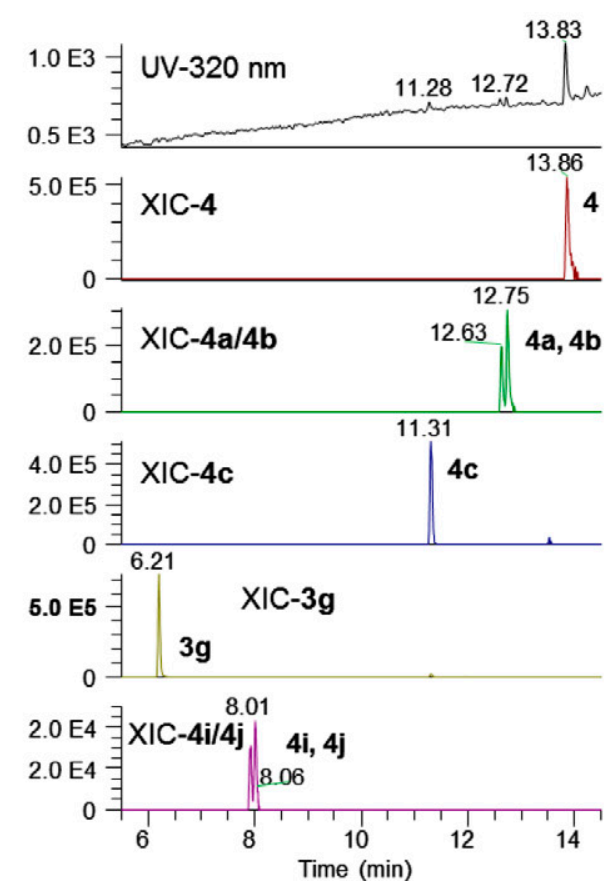

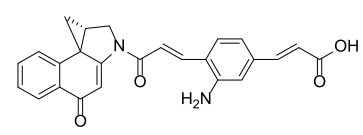

$4 \mathbf{j}$
E
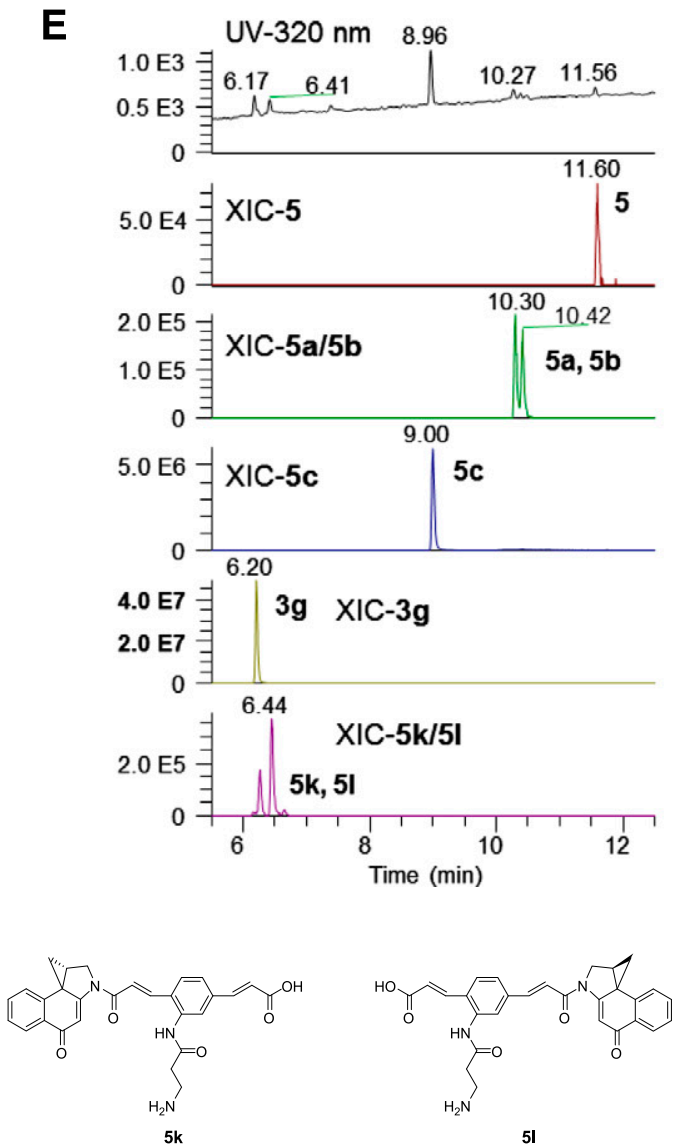

Fig. 4. Degradation products identified from compound incubation in buffer. $\mathrm{CBI} / \mathrm{CPI}$ compounds $(10 \mu \mathrm{M})$ were incubated in $10 \mathrm{mM}$ Tris- $\mathrm{HCl}$ buffer $(\mathrm{pH} 7.4)$ at $37^{\circ} \mathrm{C}$ for 24 hours before analysis. Samples were diluted four times with water or $0.1 \%$ formic acid in water and injected into LC-UV-MS/MS for analysis. Panels A, B, C, D and E are for compound $1,2,3,4$ and 5, respectively. 
TABLE 4

Normalized degradation of compound 5 in Tris- $\mathrm{HCl}$ buffer $(\mathrm{pH} 7.4)$ at $4{ }^{\circ} \mathrm{C}, 25^{\circ} \mathrm{C}$, and $37^{\circ} \mathrm{C}$ (data normalized to compound 5 MS peak area at $0.25 \mathrm{~h}$ from $4{ }^{\circ} \mathrm{C}$ group)

\begin{tabular}{|c|c|c|c|c|c|c|c|c|c|c|c|}
\hline \multirow{2}{*}{ Temperature $\left({ }^{\circ} \mathrm{C}\right)$} & \multirow{2}{*}{\multicolumn{2}{|c|}{ Compounds and Reactions }} & \multirow{2}{*}{ R.T. (min) } & \multicolumn{8}{|c|}{ Relative Amount of Products } \\
\hline & & & & $0.25 \mathrm{~h}$ & $0.5 \mathrm{~h}$ & $1 \mathrm{~h}$ & $2 \mathrm{~h}$ & $4 \mathrm{~h}$ & $8 \mathrm{~h}$ & $24 \mathrm{~h}$ & $48 \mathrm{~h}$ \\
\hline \multirow[t]{3}{*}{4} & 5 & & 11.9 & 1.0 & 0.96 & 0.72 & 0.63 & 0.62 & 0.42 & 0.26 & 0.20 \\
\hline & $5 \mathbf{a} / \mathbf{5} \mathbf{b}$ & Mono-spirocyclization & $10.5,10.6$ & 1.4 & 1.9 & 1.3 & 1.4 & 1.1 & 0.95 & 0.71 & 0.56 \\
\hline & $5 c$ & Di-spirocyclization & 9.1 & 1.3 & 2.5 & 1.7 & 2.5 & 2.3 & 2.2 & 3.5 & 3.8 \\
\hline \multirow[t]{3}{*}{25} & 5 & & 11.9 & 0.69 & 0.61 & 0.46 & 0.38 & 0.22 & 0.19 & 0.09 & 0.06 \\
\hline & $5 \mathbf{a} / \mathbf{5 b}$ & Mono-spirocyclization & $10.5,10.6$ & 1.3 & 1.2 & 0.96 & 0.81 & 0.51 & 0.48 & 0.27 & 0.20 \\
\hline & $5 c$ & Di-spirocyclization & 9.1 & 1.7 & 2.2 & 2.0 & 3.4 & 2.3 & 3.9 & 2.4 & 1.8 \\
\hline \multirow[t]{3}{*}{37} & 5 & & 11.9 & 0.50 & 0.22 & 0.13 & 0.11 & 0.08 & 0.06 & 0.05 & 0.01 \\
\hline & $5 \mathbf{a} / \mathbf{5 b}$ & Mono-spirocyclization & $10.5,10.6$ & 1.1 & 0.52 & 0.35 & 0.28 & 0.23 & 0.20 & 0.19 & 0.07 \\
\hline & $5 c$ & Di-spirocyclization & 9.1 & 3.3 & 1.4 & 1.8 & 1.8 & 2.0 & 2.2 & 3.1 & 0.90 \\
\hline
\end{tabular}

R.T., retention time.

hydrolysis than 4 (Fig. 4, D and E). Elgersma et al. also discussed the occurrence of amide hydrolysis only after spirocyclization owing to the vinylogous amide bond formed, which is consistent with the result from this study. Compounds $\mathbf{3}$ and $\mathbf{5}$ had much a higher release of alkylating group $\mathbf{3 g}$, with almost complete spirocyclization after 24 hours, whereas 4 showed much less spirocyclization and amide hydrolysis. Nevertheless, in the presence of DNA, much less degradation was observed, which was probably attributable to a protective effect of the DNA minor groove (Supplemental Fig. 3). Small fractions of chloro-seco parent compounds were even detected in the DNA precipitate after being extracted with ethyl acetate, indicating the tight binding nature of these compounds on DNA.

Solvolysis of the CPI/CBI compounds can be considered another degradation pathway, and the extent of degradation in acidic buffer has been used to assess the reactivity against common nucleophiles
(Tercel et al., 2014). However, CPI/CBIs have been shown to be mostly inert under physicological conditions (Boger and Garbaccio, 1999a). In this study, solvolysis was minimal in buffer at $\mathrm{pH} 7.4$, with only seco-CPI 2 having detectable solvolysis product 2e (Fig. 3B). Acute formic acid treatment of the samples showed increased solvolysis products of CPIs 1 and 2 but not for bis-CBIs 3, 4, and 5, indicating that CBIs were more stable and less prone to solvolysis-related degradation as previously observed (Boger et al., 1991).

Overall, acidic hydrolysis depurination was applied to CPI/CBI studies with more rapid and thorough depurination than traditional neutral thermal hydrolysis. More importantly, the acidic depurination method was capable of capturing a more representative population of DNA adducts - sometimes a different population with compound 3 -as they existed on DNA compared with the heat depurination method in which chloro-mono-adenine adducts were converted to the cyclopropyl

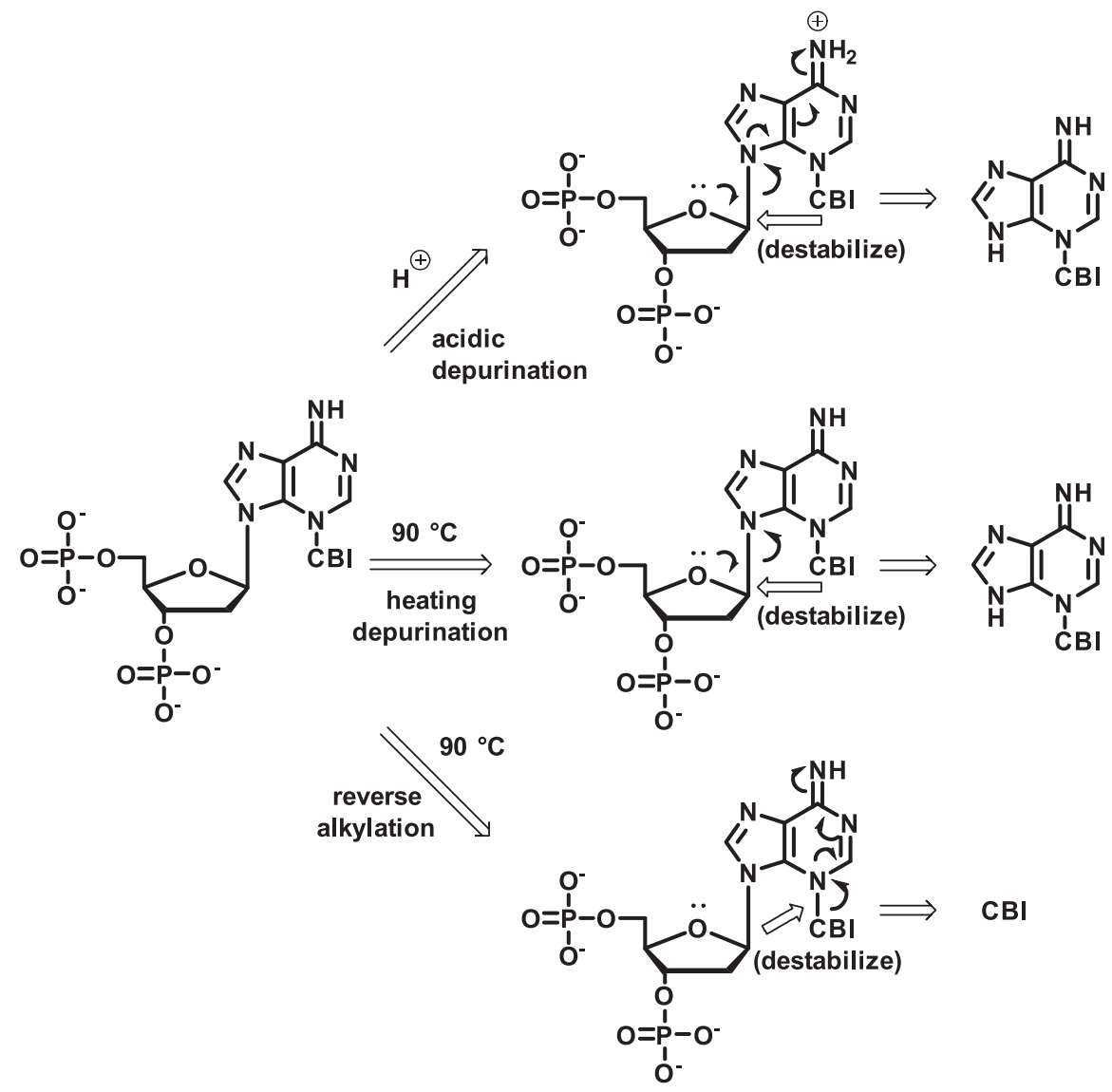

Scheme 2. Proposed mechanism of acidic depurination, heat depurination, and reverse alkylation of CBI-adenine adducts. 
forms. As a result, the di- to mono-adduct ratios for di-alkylators is consistent with their cell-killing potential. Several novel mono- and di-adenine adducts have been characterized and the DNA alkylation activity and profile can be largely affected by the type and size of the linker of bis-seco-CBIs. Although both mono- and di- alkylation adducts have been observed, mono-adenine adducts were still the major forms. The detection of a novel chloro-mono-adenine adduct as a major form also indicated a potential mechanism of direct alkylation without prior spirocyclization. In addition, the bis-seco-CBIs can rapidly undergo spirocyclization and amide hydrolysis in buffer but exhibited much higher stability in the presence of DNA. These findings should help explain in vitro-in vivo efficacy correlations and aid better design of duocarmycins as ADC payloads. The findings in this study validate an effective analytical tool to evaluate DNA alkylators and to study the DNA alkylation that is a disposition mechanism of these compounds.

\section{Acknowledgments}

We thank Marcel Hop and Andy Polson for valuable discussions in the project and Peter $\mathrm{Ng}$ for help in synthesizing and providing the oligomers. Authors were employees of Genentech, Inc.

\section{Authorship Contributions}

Participated in research design: S. Wang, Phillips, Khojasteh, D. Zhang.

Conducted experiments: S. Wang, C. Zhang, Bobba, Sangaraju, Guo.

Contributed new reagents or analytic tools: S. Wang, Pillow, Dragovich,

Staben, Ma, Su, J. Wang, Sangaraju.

Performed data analysis: S. Wang, Chen, C. Zhang, Bobba, J. Wang, Sangaraju, Wei, Phillips, Khojasteh, D. Zhang.

Wrote or contributed to the writing of the manuscript: S. Wang, Chen, J. Wang, Sangaraju, Khojasteh, D. Zhang.

\section{References}

Anderl J, Faulstich H, Hechler T, and Kulke M (2013) Antibody-drug conjugate payloads, in Antibody-Drug Conjugates (Ducry L ed) pp 51-70, Humana Press, Totowa, NJ.

Asai A, Nagamura S, Saito H, Takahashi I, and Nakano H (1994) The reversible DNA-alkylating activity of duocarmycin and its analogues. Nucleic Acids Res 22:88-93.

Baraldi PG, Bovero A, Fruttarolo F, Preti D, Tabrizi MA, Pavani MG, and Romagnoli R (2004) DNA minor groove binders as potential antitumor and antimicrobial agents. Med Res Rev 24:475-528.

Boger DL and Garbaccio RM (1999a) Are the duocarmycin and CC-1065 DNA alkylation reactions acid-catalyzed? Solvolysis pH-rate profiles suggest they are not. $\mathrm{J} \mathrm{Org} \mathrm{Chem}$ 64:5666-5669.

Boger DL and Garbaccio RM (1999b) A novel class of CC-1065 and duocarmycin analogues subject to mitomycin-related reductive activation. J Org Chem 64:8350-8362.

Boger DL, Ishizaki T, Zarrinmayeh H, Munk SA, Kitos PA, and Suntornwat O (1990) Duocarmycin-pyrindamycin DNA alkylation properties and identification, synthesis, and evaluation of agents incorporating the pharmacophore of the duocarmycin-pyrindamycin alkylation subunit. Identification of the CC-1065 duocarmycin common pharmacophore. J Am Chem Soc 112:8961-8971.

Boger DL and Johnson DS (1995) CC-1065 and the duocarmycins: unraveling the keys to a new class of naturally derived DNA alkylating agents. Proc Natl Acad Sci USA 92:3642-3649.

Boger DL and Johnson DS (1996) CC-1065 and the duocarmycins: understanding their biological function through mechanistic studies. Angew Chem Int Ed Engl 35:1438-1474.

Boger DL, Munk SA, and Ishizaki T (1991) (+)-CC-1065 DNA alkylation: observation of an unexpected relationship between cyclopropane electrophile reactivity and the intensity of DNA alkylation. $J$ Am Chem Soc 113:2779-2780.

Boger DL, Searcey M, Tse WC, and Jin Q (2000) Bifunctional alkylating agents derived from duocarmycin SA: potent antitumor activity with altered sequence selectivity. Bioorg Med Chem Lett 10:495-498.

Elgersma RC, Coumans RGE, Huijbregts T, Menge WMPB, Joosten JAF, Spijker HJ, de Groo FMH, van der Lee MMC, Ubink R, van den Dobbelsteen DJ, et al. (2015) Design, synthesis, and evaluation of linker-duocarmycin payloads: toward selection of HER2-targeting antibody-drug conjugate SYD985. Mol Pharm 12:1813-1835.
Fukuda Y, Seto S, Furuta H, Ebisu H, Oomori Y, and Terashima S (1998) The novel cyclopropapyrroloindole(CPI) bisalkylators bearing 3,3'-(1,4-phenylene)diacryloyl group as a linker. Bioorg Med Chem Lett 8:2003-2004.

Ghosh S, Majumder P, Pradhan SK, and Dasgupta D (2010) Mechanism of interaction of small transcription inhibitors with DNA in the context of chromatin and telomere. Biochim Biophys Acta 1799:795-809.

Jia G and Lown JW (2000) Design, synthesis and cytotoxicity evaluation of 1-chloromethyl-5hydroxy-1,2-dihydro-3H-benz[e]indole (seco-CBI) dimers. Bioorg Med Chem 8:1607-1617.

Jin W, Trzupek JD, Rayl TJ, Broward MA, Vielhauer GA, Weir SJ, Hwang I, and Boger DL (2007) A unique class of duocarmycin and CC-1065 analogues subject to reductive activation. J Am Chem Soc 129:15391-15397.

Kiakos K, Sato A, Asao T, McHugh PJ, Lee M, and Hartley JA (2007) DNA sequence selective adenine alkylation, mechanism of adduct repair, and in vivo antitumor activity of the novel achiral seco-amino-cyclopropylbenz[e]indolone analogue of duocarmycin AS-I-145. Mol Cancer Ther 6:2708-2718.

Kupchinsky S, Centioni S, Howard T, Trzupek J, Roller S, Carnahan V, Townes H, Purnell B, Price C, Handl H, et al. (2004) A novel class of achiral seco-analogs of CC-1065 and the duocarmycins: design, synthesis, DNA binding, and anticancer properties. Bioorg Med Chem 12:6221-6236.

Lee C-S and Gibson NW (1993) DNA interstrand cross-links induced by the cyclopropylpyrroloindole antitumor agent bizelesin are reversible upon exposure to alkali. Biochemistry 32:9108-9114.

Leung EMK, Deng K, Wong T-Y, and Chan W (2016) Determination of DNA adducts by combining acid-catalyzed hydrolysis and chromatographic analysis of the carcinogen-modified nucleobases. Anal Bioanal Chem 408:953-961.

Ma Y, Khojasteh SC, Hop CE, Erickson HK, Polson A, Pillow TH, Yu SF, Wang H, Dragovich PS, and Zhang D (2016) Antibody drug conjugates differentiate uptake and DNA alkylation of pyrrolobenzodiazepines in tumors from organs of xenograft mice. Drug Metab Dispos 44:1958-1962.

MacMillan KS and Boger DL (2009) Fundamental relationships between structure, reactivity, and biological activity for the duocarmycins and CC-1065. J Med Chem 52:5771-5780.

McGovren JP, Clarke GL, Pratt EA, and DeKoning TF (1984) Preliminary toxicity studies with the DNA-binding antibiotic, CC-1065. J Antibiot (Tokyo) 37:63-70.

Mitchell MA, Johnson PD, Williams MG, and Aristoff PA (1989) Interstrand DNA cross-linking with dimers of the spirocyclopropyl alkylating moiety of CC-1065. J Am Chem Soc 111:6428-6429.

Mitchell MA, Weiland KL, Aristoff PA, Johnson PD, and Dooley TP (1993) Sequence-selective guanine reactivity by duocarmycin A. Chem Res Toxicol 6:421-424.

Polakis P (2016) Antibody drug conjugates for cancer therapy. Pharmacol Rev 68:3-19.

Robertson WM, Kastrinsky DB, Hwang I, and Boger DL (2010) Synthesis and evaluation of a series of C5'-substituted duocarmycin SA analogs. Bioorg Med Chem Lett 20:2722-2725.

Schwartz GH, Patnaik A, Hammond LA, Rizzo J, Berg K, Von Hoff DD, and Rowinsky EK (2003) A phase I study of bizelesin, a highly potent and selective DNA-interactive agent, in patients with advanced solid malignancies. Ann Oncol 14:775-782.

Sun D and Hurley LH (1993) Analysis of the monoalkylation and cross-linking sequence specificity of bizelesin, a bifunctional alkylation agent related to (+)-CC-1065. J Am Chem Soc 115:5925-5933

Tercel M, McManaway SP, Leung E, Liyanage HDS, Lu G-L, and Pruijn FB (2013) The cytotoxicity of duocarmycin analogues is mediated through alkylation of DNA, not aldehyde dehydrogenase 1: a comment. Angew Chem Int Ed Engl 52:5442-5446.

Tercel M, Pruijn FB, O'Connor PD, Liyanage HDS, Atwell GJ, and Alix SM (2014) Mechanism of action of AminoCBIs: highly reactive but highly cytotoxic analogues of the duocarmycins. ChemBioChem 15:1998-2006.

Tichenor MS, MacMillan KS, Stover JS, Wolkenberg SE, Pavani MG, Zanella L, Zaid AN, Spalluto G, Rayl TJ, Hwang I, et al. (2007) Rational design, synthesis, and evaluation of key analogues of CC-1065 and the duocarmycins. J Am Chem Soc 129:14092-14099.

Tietze LF and von Hof JM (2011) inventors, Bifunktionale Prodrugs und Drugs.

Walker DL, Reid JM, and Ames MM (1994) Preclinical pharmacology of bizelesin, a potent bifunctional analog of the DNA-binding antibiotic CC-1065. Cancer Chemother Pharmacol 34:317-322.

Warpehoski MA, Harper DE, Mitchell MA, and Monroe TJ (1992) Reversibility of the covalent reaction of CC-1065 and analogues with DNA. Biochemistry 31:2502-2508.

Wolfe AL, Duncan KK, Lajiness JP, Zhu K, Duerfeldt AS, and Boger DL (2013) A fundamental relationship between hydrophobic properties and biological activity for the duocarmycin class of DNA-alkylating antitumor drugs: hydrophobic-binding-driven bonding. $\mathrm{J} \mathrm{Med}$ Chem 56:6845-6857.

Yasuzawa T, Muroi K, Ichimura M, Takahashi I, Ogawa T, Takahashi K, Sano H, and Saitoh Y (1995) Duocarmycins, potent antitumor antibiotics produced by Streptomyces sp. structures and chemistry. Chem Pharm Bull (Tokyo) 43:378-391.

Zhang D, Le H, Cruz-Chuh JD, Bobba S, Guo J, Staben L, Zhang C, Ma Y, Kozak KR, Lewis Phillips GD, et al. (2018) Immolation of p-aminobenzyl ether linker and payload potency and stability determine the cell-killing activity of antibody-drug conjugates with phenol-containing payloads. Bioconjug Chem 29:267-274.

Address correspondence to: Dr. Donglu Zhang, Drug Metabolism and Pharmacokinetics, Genentech, Inc., 1 DNA Way, South San Francisco, CA 94080. E-mail: zhang.donglu@gene.com; or Dr. Shuai Wang, E-mail: wangshuai66@gmail.com 